\title{
Influence of deflectorangular variation on hydrodynamic performances of single slotted cambered otter board
}

\author{
LEI Wang, LU Min Wang, WEN Wen Yu, CHUN Lei Feng,
}

\author{
JIAN Gao Shi, YONG Li Liu and XUN Zhang ${ }^{a}$ \\ East China Sea Fisheries Research Institute, Chinese Academy of Fishery Sciences, Shanghai \\ 200090, China \\ azhangxun007@hotmail.com
}

Keywords: otter board, wind tunnel test, hydrodynamic performances

Abstract: The effect of the deflector angular variation for single slotted cambered otter board on hydrodynamic performances was investigated by model wind tunnel test. Three otter board models with different deflector angle were designed for testing. The model test conducted in wind tunnel with the flow velocity at $28 \mathrm{~m} / \mathrm{s}$ and the angle of attack $\alpha$ measured from $0^{\circ}$ to $70^{\circ}$. Model experiment was conducted to obtain drag coefficients $C_{x}$, lift coefficient $C_{y}$, calculated lift to drag ratio $C_{y} / C_{x}$ and give the relations curve of these value and angle of attack $\alpha$. The result showed that the lift coefficient $C_{y}$ of No.2 otter board model was higher, there was $1.875\left(\alpha=25^{\circ}\right)$; the $C_{y} / C_{x}$ of No.1 otter board with smaller deflector angle would be higher, there was $6.555\left(\alpha=7.5^{\circ}\right)$, however, No.2 otter board model got the higher drag ratio (3.894) at the attack angle of highest lift coefficient. The results would offer reference for the structural optimization design of trawl otter board.

\section{Introduction}

Trawl doors is an important member of fishing gear for spread of trawl. The merits of otter board hydrodynamic performance can be measured by the lift coefficient of the trawl door, the drag coefficient of the trawl door and pitching moment coefficient of the trawl door. By optimizing the structure of otter board may improve hydrodynamic performance of the otter board, and reducing the energy consumption of fishing vessels. Currently, extensive studies on otter board hydrodynamic performance had been conducted in the US, Japan, Norway and other countries [1-3]; In China, researchers have studied the relevant hydrodynamic performance of otter board early since 1980s, but such researches that are focused on hydrodynamic performance differences of otter board with different structure type, and the series of optimization studies on otter board structure is still necessary [4-11]. With the development of offshore fishing, higher requirements on the otter board design is put forward, hydrodynamic performance improvement of otter board will be the focus of future research. This article is part of the series of tests, which analyze the hydrodynamic performance of otter board with different deflector angle.

\section{Material and Methods}

\section{Design and manufacture of otter board model}

Test model of otter board with a single slit curved structure is constituted by the deflectors and the main panels. Ensuring the premise of other parameters in common, the design of model structure 
has been simplified based on the test objectives and requirements, while, only the deflector angle changes. The structure and parameters of the model are illustrated in Figure 1.
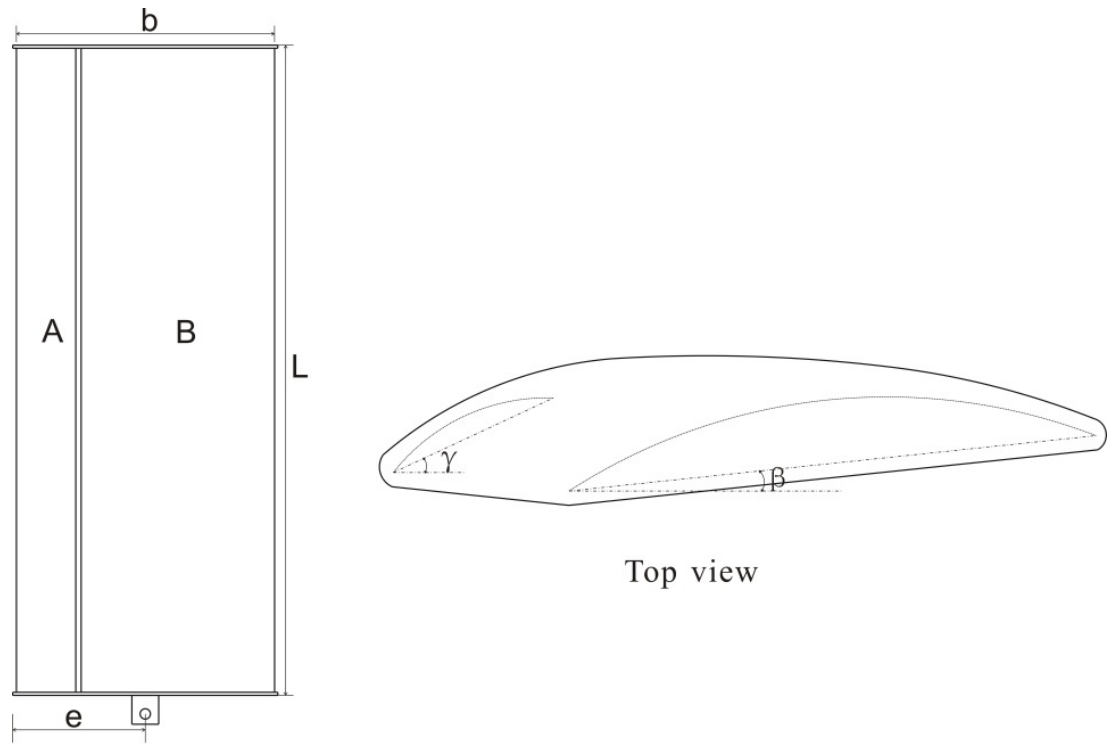

Top view

Front view

L: wing chord length; $\quad$ b: wing span length; $\quad$ e: distance between fulcrum and front end of model; $A$ : deflector; B: main plate; $\gamma$ : angle of deflector; $\beta$ : angle of main plate

Fig.1 Structure and parameters of single slotted cambered otter board

For three otter board test models, the aspect ratio is fixed at 2.5 , model's area is $0.158 \mathrm{~m}^{2}$, the corresponding length of deflectors and the main panels is same, and the curvature of the deflector and the main panel is $12 \%$, the specific parameters in Table 1, three otter board models are numbered 1,2,3 respectively. Models are made of steel with painted surfaces (Fig. 2).

Tab.1 Introductions for dimension and structure parameter of otter board

\begin{tabular}{cccccccccc}
\hline No. & $\mathrm{L} / \mathrm{m}$ & $\mathrm{b} / \mathrm{m}$ & $\lambda$ & $\mathrm{S} / \mathrm{m}$ & $\mathrm{e} / \mathrm{m}$ & $1_{\mathrm{A}} / \mathrm{m}$ & $1_{\mathrm{B}} / \mathrm{m}$ & $\gamma /{ }^{\circ}$ & $\beta /{ }^{\circ}$ \\
\hline 1 & 0.251 & 0.628 & 2. & 0.15 & 0.130 & 0.06 & 0.19 & 20 & 0 \\
2 & 0.251 & 0.628 & 2. & 0.15 & 0.130 & 0.06 & 0.19 & 25 & 0 \\
3 & 0.251 & 0.628 & 2. & 0.15 & 0.130 & 0.06 & 0.19 & 30 & 0
\end{tabular}

Note: $\mathrm{S}=\mathrm{L} \cdot \mathrm{b}$, otter board model area; $\lambda=\mathrm{b} / \mathrm{L}$, aspect ratio; leaf curvature of otter board model are $12 \%$.

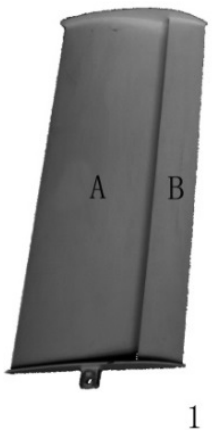

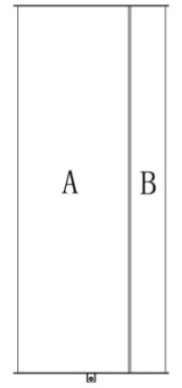

1

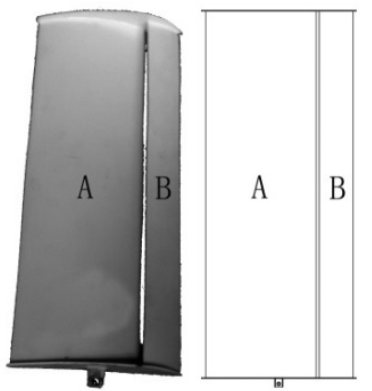

2

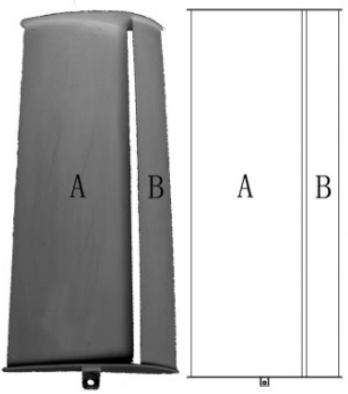

3

\section{Test facility}

Fig.2 Three otter board model and front view of design

Wind tunnel for this test is Nanjing University of Aeronautics and Astronautics NH-2 wind tunnel, the tunnel is closed reflux wind tunnel with double string test section, this experiment carried out in a small test section, the main technical performance of the small test section: $6 \mathrm{~m}$ (length) $\times 3 \mathrm{~m}$ (width) $\times 2.5 \mathrm{~m}$ (height), import cross-sectional area $7.18 \mathrm{~m}^{2}$, the maximum wind speed is $90 \mathrm{~m} / \mathrm{s}$, the minimum steady wind speed is $5 \mathrm{~m} / \mathrm{s}$. 
The dynamometer test uses six-component mechanical tower - Balances to measure, test model installation is shown in Figure 3.

Test data acquisition and processing system used is made up by the pre-amplifier and four networked computer system.

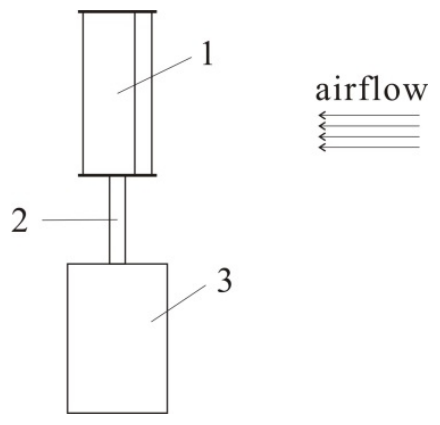

1.otter board model 2.model connection 3.six-component force balance

Fig.3 Installation instruction of otter board model in wind tunnel

\section{Test method}

Parameter definition of test model

Test model need to be installed on the wind tunnel in six-component balance mechanical base according to the order, angle of attack of model rotates by the $0^{\circ}-70^{\circ}$ when the wind speed reaches $28 \mathrm{~m} / \mathrm{s}$ (room temperature $20^{\circ} \mathrm{C}$ ), wherein the angle of attack in the range $0^{\circ}-50^{\circ}, 2.5^{\circ}$ intervals to record a measurement data point, after the attack angle $50^{\circ}$, each measurement interval of $5^{\circ}$ to record data points, there are 25 sets of data totally, including the drag coefficient $C_{x}$ and lift coefficient $C_{y}$.

The relevant parameters of models in the wind tunnel test section are defined as shown in Figure 4. In Figure 4, O is torque reference point, which is the punch of the model at the bottom. During the test, the resistance of the model provided by the balance of forces along the $\mathrm{X}$-axis direction, the lift provided by the balance of forces along the Z-axis direction.

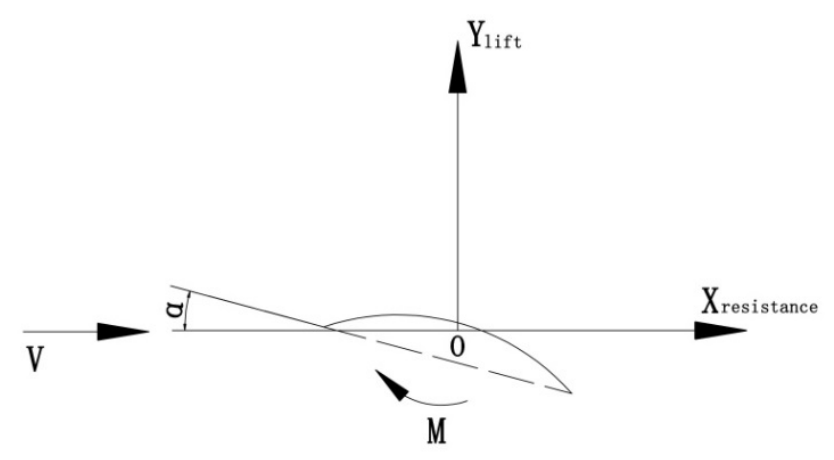

Fig.4 Parameter definition diagram of test model in wind tunnel

For this test, Wind speed $\mathrm{V}=28 \mathrm{~m} / \mathrm{s}$, when the Reynolds number $R_{e}=V L / v=0.52 \times 10^{6}$ (coefficient of viscosityv $\left.=15 \times 10^{-6} \mathrm{~m}^{2} / \mathrm{s}\right)$.

\section{Parameter definition of test measurement}

Three components: lift $Y$, drag $X$, pitching moment $M$ (around the fulcrum), while the distance from the center of pressure to the front-end otter board $d=e-(M / N)[6],(N$ is the normal force).

$$
\text { Lift coefficient } C_{y}=\frac{Y}{\rho V^{2} S / 2}[12-14] ; \text { drag coefficient } C_{x}=\frac{X}{\rho V^{2} S / 2} \text {. }
$$


Air density $\rho=1.225 P_{a} \cdot s^{2} / m$ in above formula; $S$ is otter board area $\left(\mathrm{m}^{2}\right) ; L$ is the otter board chord length (m).

All the experimental data have been carried out the stent disturbance correction which is completed by the method of taking out light pole directly.

\section{Results and Discussion}

\section{Drag coefficient and lift coefficient}

Data from the experiment includes drag coefficient $C_{x}$ and lift coefficient $C_{y} . C_{y} / C_{x}$ is the lift-drag ratio, which is a important factor to determine the merits of otter board hydrodynamic performance [13]. $C_{y} / C_{x}$ of otter board with excellent hydrodynamic properties is relatively higher. The test data is divided and made $C_{x}-\alpha, C_{y}-\alpha, C_{y} / C_{x}$ - $\alpha$ graph shown in Figure 5 for analyzing the differences of hydrodynamic properties of three otter board models clearly.
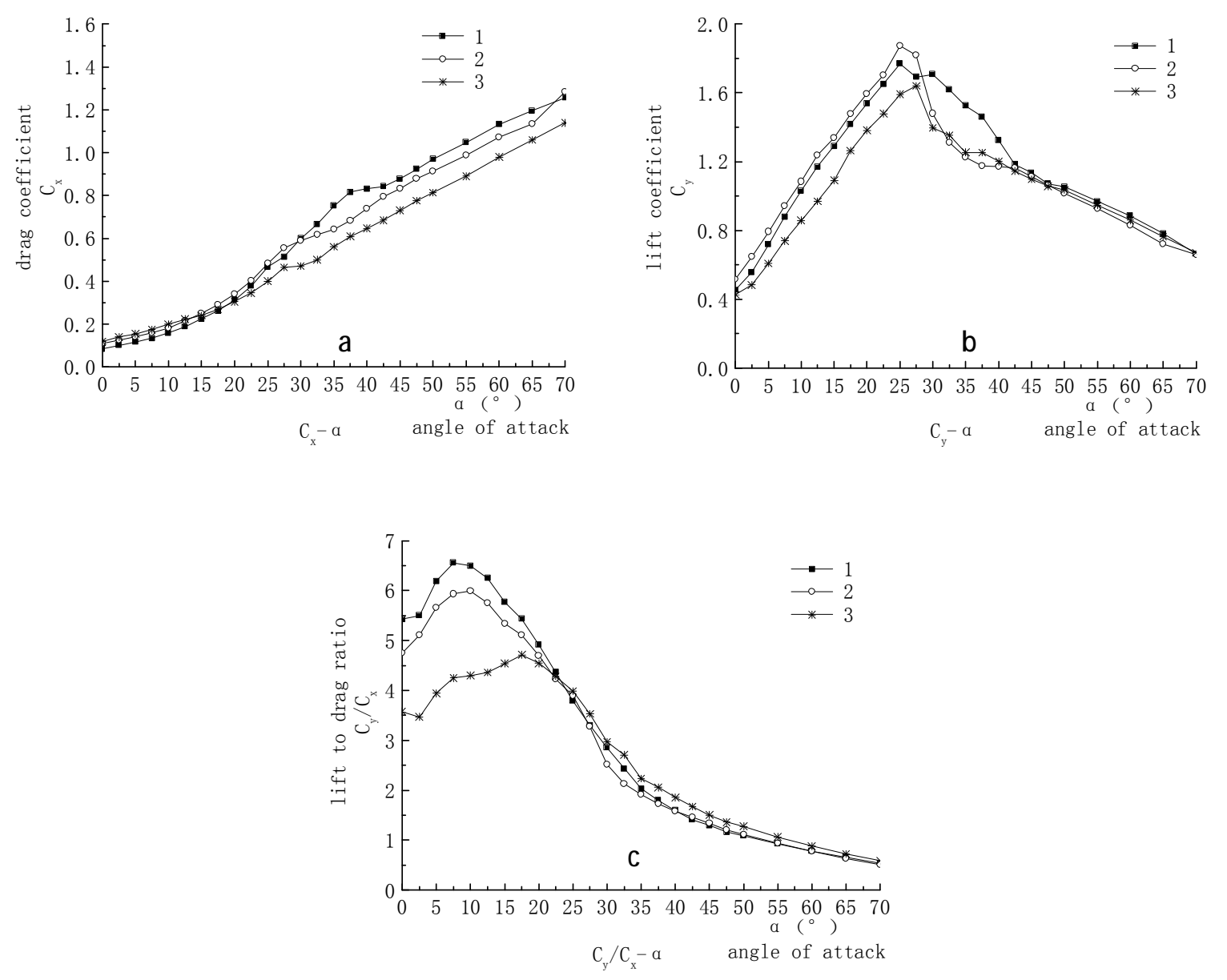

Fig.5 The changing curve grouping comparison of $C_{\mathrm{x}}(\mathrm{a}), C_{\mathrm{y}}(\mathrm{b})$ and $C_{\mathrm{y}} / C_{\mathrm{x}}(\mathrm{c})$ along with the angle of attack $\alpha$ changed for three otter board models

In Figure 5, graph $C_{x}-\alpha$ and $C_{y^{-}}-\alpha$ show that the variation curve of drag coefficient $C_{x}$ and lift coefficient of three models while the angle of attack $\alpha$ changed. The relationship between $C_{x}$ and $\alpha$ is proportional, $C_{x}$ of model No. 3 is lower after the angle of attack $25^{\circ}$, the results show that $C_{x}$ of otter board reduced with the deflector angle decreasing; $C_{y}$ of No. 2 model is higher before the angle of attack $27.5^{\circ}$, the maximum lift coefficient was $1.875\left(\alpha=25^{\circ}\right)$, the maximum lift 
coefficient of No. 1 and No. 3 otter board model were $1.770\left(\alpha=25^{\circ}\right)$ and $1.640\left(\alpha=27.5^{\circ}\right)$ separately. Generally, the maximum lift coefficient $C_{y}$ of No. 2 model in three models is the highest (deflector angle $25^{\circ}$ ).

\section{Lift-drag ratio}

In Figure 5, the curve $C_{y} / C_{x^{-}} \alpha$ shows that the lift-drag ratio $C_{y} / C_{x}$ of No. 1 otter board model is higher when the angle of attack $\alpha<22.5^{\circ}$, and the maximum lift-drag ratio is $6.555\left(\alpha=7.5^{\circ}\right)$, the maximum lift-drag ratio of No. 2 and No. 3 model were $5.991\left(\alpha=10^{\circ}\right)$ and $4.716\left(\alpha=17.5^{\circ}\right)$, respectively. Comparative analysis in three models, the maximum lift-drag ratio of the otter board is gradually decreased with the increase of deflector angle, and lift-drag ratio decreased rapidly when the deflector angle increased. Under normal circumstances, the maximum lift-drag ratio corresponding to the angle of attack, which corresponds to the lift coefficient is often not the highest, in fact, the lift-drag ratio size corresponding to the angle of attack near the maximum lift coefficient is also important. The lift-drag ratio of No. 1 model is 3.789 when the angle of attack is $25^{\circ}$ (corresponding tothe maximum lift coefficient), the lift-drag ratio of No. 2 model is 3.894 at the angle of attack of $25^{\circ}$, and No.3 is 3.530 at the angle of attack $27.5^{\circ}$, comparatively speaking, the hydrodynamic performance of No. 2 otter board model is better.

\section{Conclusions}

The test concluded that the smaller deflector angle could increase the resistance of otter board, the larger deflector angle could decrease the lift-drag ratio, and the proper deflector angle could reduce the drag and improve the lift of otter board.Tests showed that the otter board with the deflector angle $25^{\circ}$ got a higher maximum lift coefficient, and a higher lift-drag ratio at the angle of attack which corresponds to the maximum lift coefficient, so in such three otter board models for experimental design, the No. 2 otter board model has a better hydrodynamic performance. This conclusion can be used as a reference in deflector angle design of otter board, follow-up tests will be carried out to test in other factors, in order to achieve the ultimate goal to optimize and improve the efficiency of the otter board.

\section{Acknowledgements}

This work was financially supported by the National Key Technology R\&D Program (No. 2013BAD13B03).

\section{References}

[1] A. A.SALA, J. P. FARRANB and J. ANTONIJUAN: Fisheries Research, Vol.100 (2009), p.156.

[2] M. K. BROADHURST, D. J. STERLING and B. R.CULLIS: Fish Res, Vol.131/133 (2012), p.67.

[3] Y. TAKAHASHI, Y. FUJIMORI and F. X. HU: Fisheries Research, Vol.161 (2015), p.400.

[4] X. Zhang, M.Y. Wang and B.S. Xu: Journal of Fishery Sciences of China, Vol.S1 (2004), p. 107. In Chinese.

[5] X. Zhang, J.H. Wang and M.Y. Wang: Journal of Fishery Sciences of China, Vol.S1 (2004), p.5.

[6] M.Y. Wang, J.H. Wang and X. Zhang: Journal of Fisheries of China, Vol.28 (2004), p.311.

[7] J. Liu, H.L. Huang and Y. Chen: Fisheries Modernization, Vol.42 (2015), p.50.

[8] J. Liu, H.L. Huang and Y. Wu: South China Fisheries Science, Vol.11 (2015), p.68. 
[9] B.S. Xu, X. Zhang and M.Y. Wang: Journal of Fujian Fisheries, Vol.1 (2010), p.86.

[10]B.S. Xu, X. Zhang and Y.F. Yu: Marine Fisheries, Vol.28 (2006), p.66.

[11]C.C. Li, Z.L. Liang and L.Y. Huang: Marine Sciences, Vol.37 (2013), p.69.

[12] Y.Q. Zhou: Mechanics of fishing gear (China Agriculture Publications, Beijing 2001).

[13] G. X. Guo, T.Y. Liu and X.H. Huang: Theory and Practice of trawl doors Kinetic (: Guangdong Science and Technology Publications, Guangzhou 2008).

[14]X.Z. Chen and X.C. Huang: Theory and method of gear model test (Shanghai Science and Technology Publications, Shanghai 2011). 